\title{
COPTIC LITURGICAL TEXTS RELATING TO AGATHON THE STYLITE
}

\author{
Textos litúrgicos coptos sobre San Agatón el estilita
}

\author{
Youhanna Nessim Youssef ${ }^{\mathrm{I}}$
}

\begin{abstract}
While Egypt was the cradle of monasticism since Antony, the stylite type of monasticism is rarely represented in the Coptic corpus of monastic literature. Hence every text will contribute to our knowledge. In this article, we will highlight the importance of the city of Sakha, in the book of history of the Patriarchs, the book of the Churches and Monasteries (twelfth century). The liturgical texts relating to this saint are exceedingly rare, hence the importance publishing all texts. We will edit, translate all the liturgical texts relating to one of this group, we were able to find a doxology Batos not attested in most of the manuscripts as well as the texts of the Antiphonarion (Difnar). It is important to mention that this saint lived in Lower-Egypt around the sixthseventh century which means that it was around the time of important events such as the usurper of Phocas, the Persian invasion, the Byzantine reconquest, and the Arabic conquest. He was influenced by the biography of the great Simon the Stylite. Nowadays, no traces of his cult survive in Sakha which explains the rarity of manuscripts containing anything relating to this saint, however Sakha is nowadays known as a step of the journey of the Holy Family.
\end{abstract}

Keywords: Coptic monasticism; Coptic Liturgy; History; Late Antiquity in Egypt; Coptic Manuscript; Agathon the Stylite; Monastic Order.

$1 \mathrm{PhD}$ in Coptology, Montpellier University, Paul Valery, France. Senior lecturer at Stockholm School of Theology, Sankt Ignatios college, University College Stockolm, Sweden. Associate Professor (Honorary), St Athanasius University of Divinity, Australia. Email: ynyoussef@hotmail.com. 


\section{Resumen}

Aunque Egipto fue la cuna del monacato desde San Antonio, el tipo de monacato estilita pocas veces es abordado en el corpus copto sobre literatura monástica. En este artículo se resalta la importancia de la ciudad de Saja, el libro de la Historia de los Patriarcas, y el libro de las Iglesias y Monasterios (s. XII). Los textos litúrgicos sobre San Agatón el estilita son sumamente raros, de allí la importancia de su publicación. Por lo tanto, aquí se editan y traducen todos los textos litúrgicos relacionados con esta temática. Además, se encontró una doxología a la melodía de Batos que no está declarada en casi ninguno de los manuscritos ni en los textos del Difnar (Antifonario). Es relevante mencionar que este santo vivió en el bajo Egipto alrededor de los siglos VI y VII, lo cual significa que fue cronológicamente cercano a acontecimientos importantes como la usurpación de Focas, la invasión persa, la reconquista bizantina y la conquista árabe. Asimismo, fue influenciado por la biografía de Simeón Estilita el Viejo. En la actualidad no existe ningún rastro de su culto en Saja, lo cual explica la escasez de manuscritos que contengan información sobre él. A pesar de esto, Saja es conocida en la actualidad como un paso del viaje de la Sagrada Familia.

Palabras clave: Monacato copto; Liturgia copta; Historia; Antigüedad tardía en Egipto; Manuscrito copto; Agatón el estilita; Orden monástica.

\section{Introduction}

While Egypt was the cradle of monasticism since Antony, the stylite type of monasticism is rarely represented in the Coptic corpus of monastic literature. Agathon is one of few Egyptian monks to be a stylite on a pillar near Sakha. While the city is well attested in Coptic history, amazingly enough we do not find any traces about this saint.

In this paper, we will overview the history of the church in Sakha from the available sources, such as the book of the History of the Patriarchs or the Book of the Churches and Monasteries. then we will study the veneration of Agathon the Stylite in the liturgical calendars. We will study the liturgical texts relating to Agathon the Stylite with a brief commentary. Finally, we will make a short a conclusion.

\section{Sakha}

\section{In the fourth century,}

The name of Sakha is a stronghold of Christianity. According to the martyrdoms of the great persecution in the fourth century, we know that there was a priest called Anua, priest of Sakha that the two brothers Piroou and Athom (Hyvernat, 1886-1887, p. 135-173) collected his relics of and deposited them in the church at Sunbat (Viaud, 1979, p. 26; Viaud, 1991, p. 1968a-1975b). 
Balana (feast day: $8 \mathrm{Abib}$ ), a priest from Bara in Sakha district who sold his goods and distributed the proceeds to the poor. He professed his faith before the governor Arianus in Antinoopolis and was tortured and beheaded.

The seat of Sakha is mentioned in a letter written by Athanasius (Timm, 1992, pp. 2686-2694).

Agathon was contemporary to the great bishop Zacharias of Sakha (Müller, 1991, pp. 2368a- 2369a; Evelyn-White, 1932, pp. 276-280) and Agathon like him was disciple of the Abraham and George (Coquin, 1991, pp. 12a-13a) the disciples of John the Hegumen of Scetis (Zanetti, 1996, pp. 273-405) "the last great saints" (Evelyn-White, 1932. pp. 278-280).

\section{Sakha in the book of the History of the patriarchs}

\section{In the sixth century}

Severus of Antioch reposed in Sakha in the year 538 in the house of local notable called Dorotheus. ${ }^{2}$

\section{In the seventh century}

From Sakha at this time also came one of the compilers of the History of the Patriarchs, a monk named George (Jurja or Mirka) from the monastery of St. Macarius. ${ }^{3}$

During the patriarchate of Agathon the patriarch (661-677) (who is also contemporary to Agathon the Stylite) an incident showing the state of confusion between Chalcedonians and anti-Chalcedonians occurred in the city of Sakha, which was predominantly under the influence of a Chalcedonian majority. It had a magistrate, an archon by the name of Isaac, who, in conjunction with its Muslim governor, was able to prevail over the Chalcedonian majority. The viceroy of Egypt at the time was Maslamah ibn Makhlad ibn Samit al-Ansari (667-689). He sent seven bishops to Sakha to make an inquiry into the accusation that some officials had been branded. Together with Isaac, who was obviously a follower of Agathon the patriarch, the situation was clarified, and the accused were absolved. The life of Agathon the Stylite does not make any allusion to this event, which took place in his city. ${ }^{4}$

The patriarch Isaac (686-689AD) was a disciple of Zacharias the bishop of Sais, (Porcher, 1915, pp. 14-15) and before his ordination, there was another candidate called George from Sakha (Evetts, 1909, p. 276 [22]) which shows that Sakha maintained its reputation.

2 For the primitive of this book cf. Seybold, 1912, pp. 83. For the Vulgata cf. Seybold, 1904, pp. 90. Evetts, 1909, p. 193. For other sources cf. also Youssef, 2004, p. 504 [140]-505[141]; Id, Youssef, 2006, p. 66-67.

3 Moawad, 2014, pp. 4-18; Atiya, 1991, pp. 20a-20b. For the primitive of this book cf. Seybold, 1912, pp. 120.

4 For the primitive of this book cf. Seybold, 1912, pp. 114-115. For the Vulgata cf., Evetts, 1909, p. 9 [263]. Müller, 1991, pp. 65a-66b. 


\section{In the ninth -Tenth centuries}

The prosperity of Sakha continued as this is apparent from the biography of the patriarch Cosmas (851858) who died while he was preparing a church in the diocese of Sakha (Abd al-Masih \& Burmester, 1943, pp. 12 - 17, Translation: Labib, 1991, pp. 636b- 637b).

His successor Kha'il III, (880-907AD) (Labib, 1991, pp. 1412b-1413a). When he went to consecrate the church of Ptolomy at Sakha, when the bishop of Sakha was absent, the patriarch offered the liturgy which made the bishop angry and the dared to throw the oblation. By the end, the patriarch excommunicated the bishop and ordained another one (Abd al-Masih \& Burmester, 1948, p. 70, (text) pp.103-104.).

\section{In the Eleventh century}

The bishop of Sakha, John known as Ibn al-Zalim, the scribe before his episcopate led a group of bishops and a body of the priests of Alexandria to go to Cairo and they made agreement to depose the father Christodoulus from the patriarchate as John the bishop of Sakha had quarrel with the patriarch. This plot was unsuccessful (Abd al-Masih \& Burmester, 1959, pp. 172-173 (text), pp. 260-262 (translation)). This bishop John of Sakha was also among the delegation that chose Cyril II (Labib, 1991, pp. 675b-677a) the successor of Christodoulus (Abd al-Masih \& Burmester, 1959, p. 207 (text), p. 321 (translation)).

\section{In the book of the churches and Monasteries Twelfth century}

According to the book of the churches and Monasteries ascribed to Abū al Makarim ${ }^{5}$ mentions about the church of al Mahallah al-Kubra, that was renovated in the reign of Senutiu who is Shenūde the $65^{\text {th }}$ from the number of the Patriarchs and the bishop Anba Maqarah the bishop of Sakha in the year 754 of the Martyrs (1038AD) (Al-Suriani, 1984, fol.b-33a). While talking about Sakha, he highlights that it has a church named after the Virgin Mary where Severus of Antioch used to dwell in it, and another church named after the Archangel Michael, a third one dedicate to saint Cyr and two churches named after George and finally a church in Difraya near Sakha named after the Virgin and known also for the many miracles that took place in it (Al-Suriani, 1984, fol. 34a-b).

The same author narrates the conflict between the bishop of Sakha and the Patriarch Kha'il III the $46^{\text {th }}$ (744-767) (Labib, 1991, p. 1410b-1412a) and how he excommunicated that bishop. ${ }^{6}$ Finally Abu al-Makarim states that according to the history of the Patriarchs that the biography of Theodosius the

5 Our references refer to the edition of Samuel al-Suriani, 1984, Vol. 1 Cairo 1084, and also Evetts and Butler, 1895. For specific studies cf. Samuel al-Suriani, 1990, p. 78. (For codicology and Composition) Zanetti, 1995, p. 85133. (For the Authorship and Influence) Den Heijer, 1993, pp. 209-219. (Social study of the Delta) Martin, 1997, pp. 181-199. Martin. 1998, pp. 45-49. Martin, 2000, p.83-92. Martin, 2004, p.313-320. Youssef, 1998-1999, p. 45-54. den Heijer, 2007, p. 91-107. Mouton and Popescu-Belis, 2006, p.: 1-53.

6 al-Suriani, 1984 , fol. $38 \mathrm{a}-\mathrm{b}$, this event is relating to Kha' il III the $56^{\text {th }}$ patriarch not the Kha' il I the $46^{\text {th }} \mathrm{cf}$. supra. 
patriarch the $33^{\text {rd }}$ that Dorotheus from Sakha restored and built monasteries and keeps instead of what were destroyed by the impious king Justinian and his companions (Al-Suriani, 1984, fol. 73b).

\section{Conclusion}

Despite the abundant data that we possess about the city of Sakha, nothing is mentioned about Agathon the Stylite which means that from the seventh to the twelfth centuries, there was no veneration for Agathon.

\section{The Calendars}

The Synaxarion on the 14 Tūt (Forget, 1905, p. 76 ; Basset, 1904, p. 364[150]) commemorates:

\section{The Departure of St. Agathon the Stylite}

On this day St. Agathon the Stylite, departed. He was from the city of Tannīs. The name of his father was Matra and his mother's name was Mariam. They were righteous and feared God. They loved to give alms and be merciful to the poor and needy. The thought of monasticism was always on his mind. When he was 35 years old, he was ordained priest, and he devoted himself to serve the holy church. He asked the Lord Christ by day and night to facilitate for him the parting from this world to go to the desert. The Lord Christ answered his request, and he went out from the city and came to Ternot (Mareot) and from there went to the desert. The angel of God appeared to him in the form of a monk who journeyed with him and brought him to the monastery of St. Macarius in Scetis. He came to the holy old men Abba Abraham and Abba George, became their disciple, and remained with them for three years. Then, they took him before the altar and in the presence of the Hegumen Abba John and for three days they prayed over the monastic garb. They then ordained him a monk and dressed him with the holy Scheme. From that hour he exerted himself with many worships, in continuous fasting and prayer and fought a great fight. He slept on the ground until his skin cleaved to his bones. He read continually the biography of Abba Simon the Stylite, and he thought of leading a solitary life. He took counsel with the holy fathers concerning that, and they approved his wish and they prayed for him. He left and came near the city of Sakha, province of Gharbia, where he dwelt in a small church. The believers built a place for him on a pillar, and he went up on it. During his days, a man appeared in whom dwelt an obstinate devil, who led many people astray. He sat in the middle of the church surrounded by people listing to him, carrying tree branches. Abba Agathon sent for the possessed and had him brought to him. He prayed over him and cast out the devil who led the people astray. Similarly, a woman claimed that St. Mina conversed with her and she commanded the people of her city to dig a well in the name of St. Mina to heal everyone who bathed in it. St. Agathon prayed down of martyrdom in the kingdom of the heavens. May his prayers be with us over that woman until he cast out from her that unclean spirit and he commanded the people to fill up that well with earth. At the hands of this holy man, St. Agathon, God worked many miracles, of healing sick people and casting out devils. The devils appeared to him in the form of angels, singing sweet songs and imparting blessings unto him, but by the might of the Lord Christ he knew their guile, 
he made the sign of the Cross over them, and they fled away defeated. When God wished to repose him from the labours of this world, he fell sick for a short while and delivered up his soul into the hand of God. The people who had benefitted from his sermons and teachings gathered around him and wept bitterly. This holy father lived for 100 years, of which he spent 40 years in the world and 10 years in the desert and 50 years in solitude upon that pillar. His prayers guard us against all our enemies, and Glory be to our God, forever. Amen.

Only one manuscript of the Menologus of the Gospels (14 Tūt) mentions Agathon the stylite ${ }^{7}$ and in the calendar of Abu Barakat Ibn Kabar (14 Tüt) we find the name of Agathon as saint, (not stylite) (Tisserant, 1913, p $254[10])^{8}$ in the calendar of Qalqašandì: feast of Simeon the recluse (Coquin, 1975, pp. 375-411 especially p. 389), but he is not mentioned in the calendar of Ibn al-Rahib, as we find Isaac the recluse (Sidarus, 1975, Tafel 7). Amazingly enough, we find the Syriac calendar commemorates Agathon the stylite $\left(7-8^{\text {th }}\right.$ century) on the $12^{\text {th }}$ of September (Iylü.l) (Akhrass, 2015, p. 135). There are neither relics recorded, ${ }^{9}$ nor inscriptions mentioning his name (Papaconstatinou, 2001, p. 55).

\section{In the liturgical books}

This saint is not mentioned in the manuscripts used by Bishop Samuel for his edition of the book the Order of the Church "Tartīb al-Bay'ah". This commemoration does not occur in the book of Turūhāt (Burmester, 1938, pp. 141-194 especially p.148). Yassa 'Abd al-Masih did not find any doxology in the seven manuscripts that he used for his article (Abd al-Masih, 1941, pp. 31-61 especially p. 38), the same could be said for the Ms Paris Copte 123, which is the book of doxologies for the first six months of the year. There is a group of monks who are called the stylites in the Coptic lectionary, this group includes Simeon the Stylite, Agathon, the Stylite, Luke, Barsuma, and Theodore disciple of Pachome, Pachome, Marcian, Simeon the young, Moses the black and Ephrem the Syrian (De Fenoyl, 1960, pp.51-53).

\section{The Manuscript 75 Liturgy Sammanūd}

The manuscript contains the doxologies and responses for the first three months i.e. Tūt, Babāh and Hatūr. The numbering is in Coptic Uncial on the verso. The text starts on ff. 4 and the last part of the text 168 and the colophon is written by error as $\mathrm{f} .199$.

The colophon includes several important data; we will give the text in full.

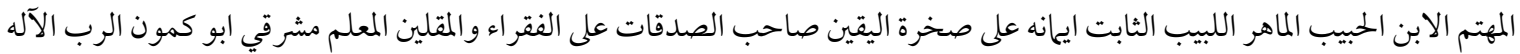

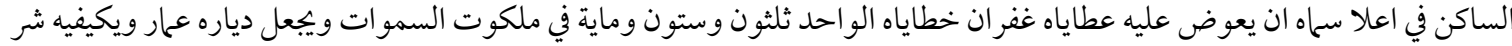

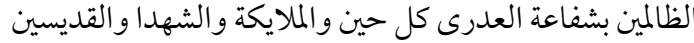

7 Nau, 1913, p. 223[59] (Agathon the Stylite), the other manuscripts that did not mention are in the following pages : p. 188[2], p.211[47], p225[61].

8 Mar Agathon, Saint, Ananias Bishop.

9 We did not find any relics their names should be mentioned in the following pages: Meinardus, 1970, p. 152 (nothing). Meinardus, 1999, p 312 (nothing). 

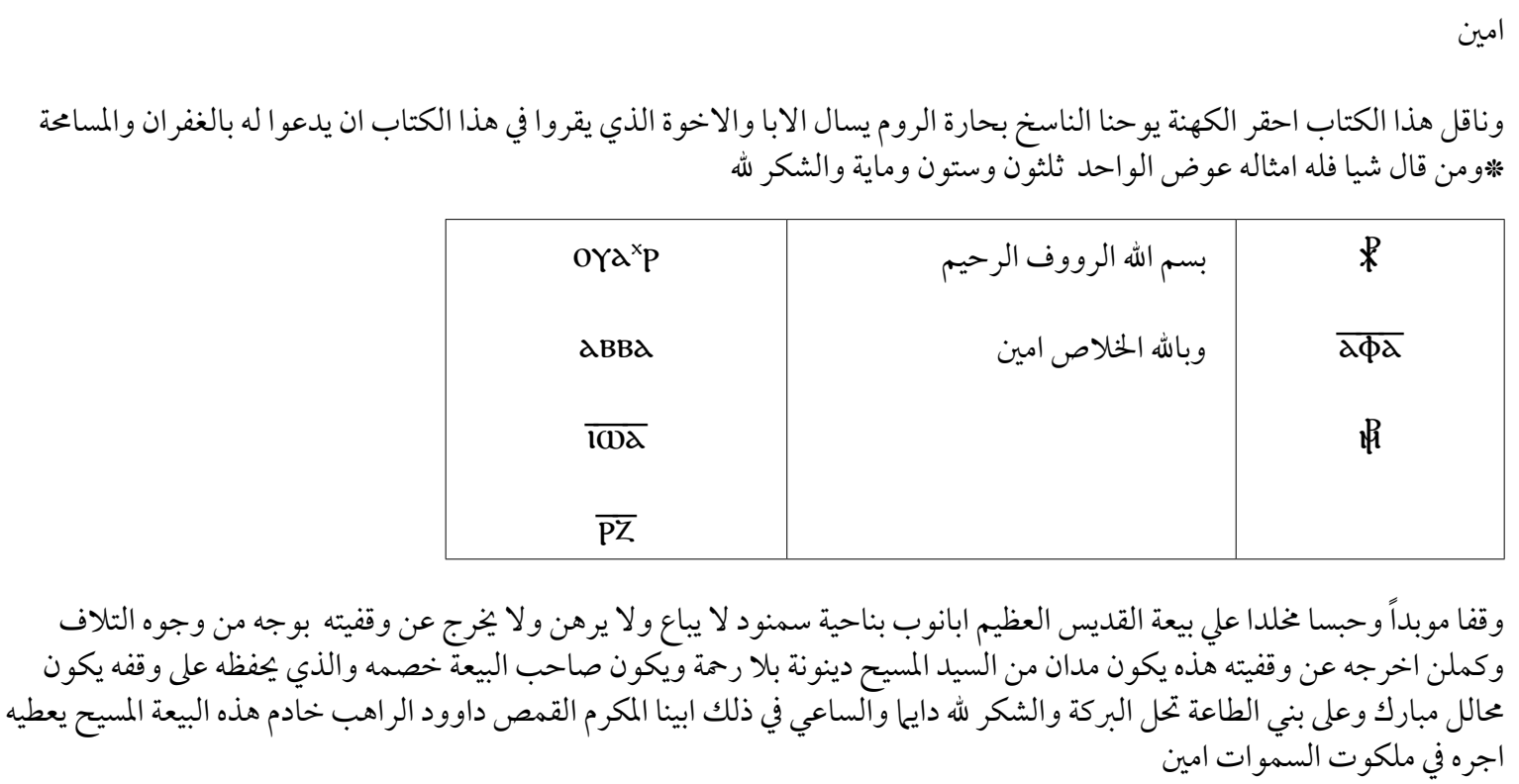

The sponsor is the beloved son, the clever, intelligent, the established in his faith on the unshakable rock who gives alms to the poor and needy, the master (Mu'allim) Mišriqī Abū Kammūn, may the Lord God dwelling in the Highest Heaven reward his gifts forgiveness of his sins thirty, sixty and one hundred in the heavenly kingdom and will make his houses inhabited and protect his from the evil of the oppressors through the intercessions of the ever Virgin, the Angel, the martyrs and the saints. Amen

The scribe of this book the most humble of the priest, Yūhannā the scribe in Harit al-Rūm demands the fathers and brethren who read in this book to pray for the forgiveness and pardon and who says anything will get the same thirty, sixty and one hundred, thanks be to God.

The archbishop Abba John the 107 in the time of the martyrs $1501(=1785 \mathrm{AD})^{10}$

In the name of God the compassionate and merciful

The salvation is from God Amen

(This is) an inalienable endowment and eternal bequest for the church of the great saint Abanūb in the district of Sammanūd not to be sold or taken in pledge or taken out of his bequest for any reason of destruction. Whoever will take it out of his bequest will be condemned by Lord Christ condemnation without mercy and the patron saint of this church will be his adversary and whoever will keep it in its bequest will be absolved and blessed. May the sons of the obedience will get the blessing. Thanks be to God forever and who worked for that our honoured father Dawūd the monk the minister of this church, may Christ grant him his wage in the heavenly kingdom Amen!

10 In Coptic 
The History of the Patriarchs is nearly silent (Khater \& Burmester, 1970, p 294 (Translation), p. 169 (text)). The patriarch John XVIII started to establish the patriarchal library in Harit al-Rūm (Atiya, 1991, p. 1206b-1207b; Butler, 1887; pp. 278-284), unfortunately, we do not know the exact location of this library as the present edifices date from the time of Muhammad 'Ali. (Meinardus, 1977, p. 304-305; 1999, p.196).

The colophon highlights also that the minister of church of Sammanūd is a monk, however we do not know the name of his monastery. It is worth mentioning that the sponsor of this manuscript is a layman. The role of the notables increased especially in the eighteenth century. ${ }^{11}$

\begin{tabular}{|c|c|}
\hline نياحة اغاتا العامودي دكصولوجية واطس عشر شتر توت & $\begin{array}{l}\text { The fourteenth day of the month of Tüt } \\
\text { Repose of Agathon the Stylite }\end{array}$ \\
\hline 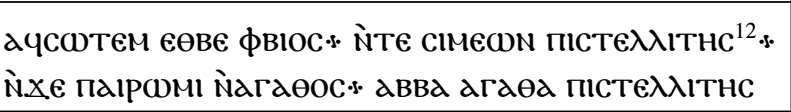 & the \\
\hline 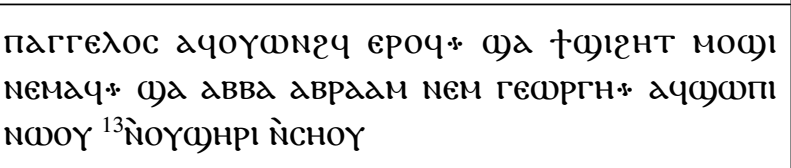 & $\begin{array}{l}\text { The an } \\
\text { to Scet } \\
\text { he dwe }\end{array}$ \\
\hline 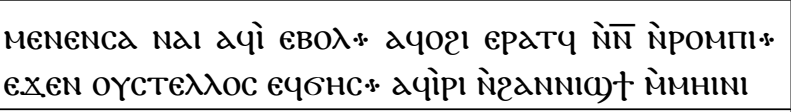 & on a \\
\hline 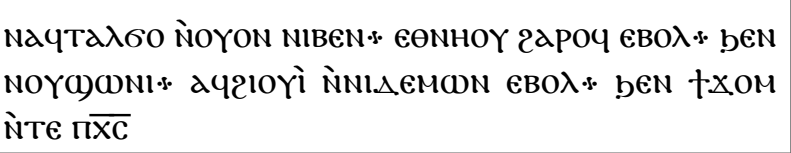 & $\begin{array}{l}\text { He used to } \\
\text { illness, he ca } \\
\text { Christ }\end{array}$ \\
\hline 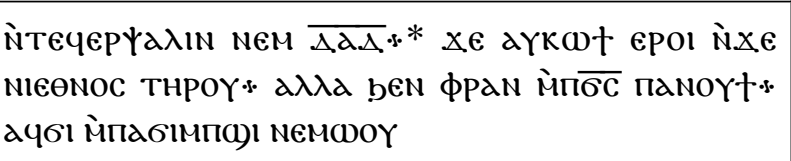 & $\begin{array}{l}\text { To sing with David: "All nations surrounded me, } \\
\text { but in the name of the Lord, my Lord I fended } \\
\text { them off?"14 }\end{array}$ \\
\hline 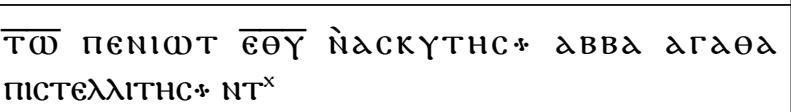 & $\begin{array}{l}\text { Prayer...our holy father the ascetic one Abba } \\
\text { Agathon the Stylite that }\end{array}$ \\
\hline
\end{tabular}

\section{Commentary}

The first quatrain, the text seems to be written in Arabic дгдөd as it should be the Greek vocative arde€

[Magdi Girgis, The influence of the notables on the situations, p. 9-18.

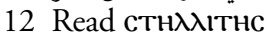

13 Read nєм0о

14 Ps 117 [118]: 10 
The text highlights the main reason that motivated him to become a Stylite is the reading of the life of Simon that was translated in Coptic and was published according to the manuscript 61 Vatican Library which dates to the tenth century (Cf. Chaîne, 1948). The quatrain states that an angel appeared to him and walked with him to Abba Abraham and George however the expression for a while "Noүo)нрı ஸेсноү" seems to be an Arabic idiom.

The fifth quatrain is taken from the doxology of Saint George, while in the doxology of Saint George is in the context, the use of this doxology is out of context. The text also mentions the duration of the saint on the pillar and the miracles The conclusion is the usual demand for the prayers of the saint. The doxology is another source of information of the life of Agathon the Stylite.

\section{The Difnar ${ }^{15}$}

This book was first compiled in the Upper-Egypt (Sahidic) (Krause, 2003, p 167-185; Cramer \& Krause, 2008, p. 17-21) before the ninth century. The first manuscript that came to our knowledge in LowerEgypt (Bohairic) dialect is from the monastery of Saint Antony as this is apparent from the colophon of the Manuscript of Saint Antony.

$$
\begin{aligned}
& \text { كمل شهر بابه المبارك بمعونة ربنا يسوع المسيح الذي يحق له التمجيد ةالتسبيح الى اباد الدهور وعلينا رهمته امين } \\
& \text { نجز في اخر شهر كيهك لسنة الف وماية واحد للشهداء الاطهار بدير القديس العظيم انبا انطونيوس ببرية العببة ربنا يسوع المسيح يصنع }
\end{aligned}
$$

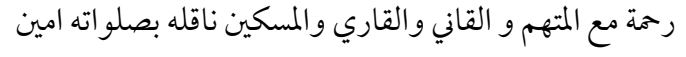

The month of the blessed month of Bābah is finished -with the help of our Lord Jesus Christ- to him is the glorification and praise for ever Amen- May his mercy be upon us Amen!

It was accomplished on the last day of Kihak of the year 1101 of the pure martyrs (= 26 December $1384 \mathrm{AD}$ ) in the monastery of Antony in the desert of Arabah. May our Lord Jesus Christ have mercy upon the sponsor, the owner, the reader and the poor scribe, through his prayers, Amen!

All the other existing copies -containing the full Coptic text- are mainly taken from this manuscript

\begin{tabular}{|c|c|c|}
\hline س اغاثا العمودي من تنيس & 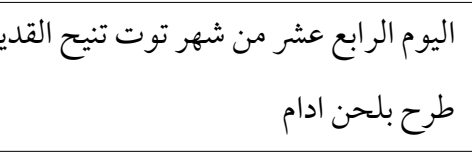 & $\begin{array}{l}\text { The } 14^{\text {th }} \text { day of the month Tüt, } \\
\text { the repose of saint Agathon the } \\
\text { Stylite from Tannis }\end{array}$ \\
\hline 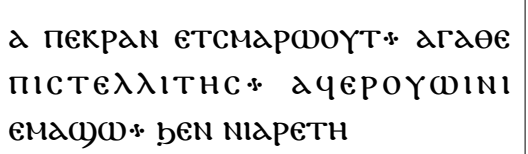 & بالاكثر في المضارك يا انبا اغاثا العمودي اضي & $\begin{array}{l}\text { Your blessed name Athagon the } \\
\text { stylite extremely shines by the } \\
\text { virtues }\end{array}$ \\
\hline
\end{tabular}
(Mekhaiel, 2010, p. 34-58).

15 For this book cf. Gabra, 1996, p. 37-52; 1998, p. 48-69. 


\begin{tabular}{|c|c|c|}
\hline 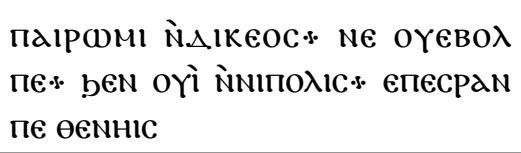 & تدذا الرجل الثابت كان من اهل بلد & $\begin{array}{l}\text { This just man was from one } \\
\text { of the cities which its name is } \\
\text { Tannis }\end{array}$ \\
\hline 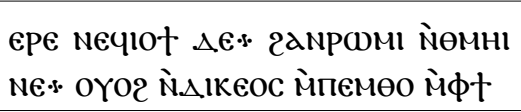 & واللهانوا ابهاته اناس ابرار وصديقين امام & $\begin{array}{l}\text { His parents were righteous and } \\
\text { just people in front of God }\end{array}$ \\
\hline 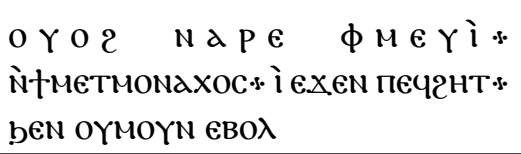 & فتور & $\begin{array}{l}\text { And the thought of } \\
\text { monasticism came always }{ }^{16} \text { to } \\
\text { his } \text { mind }^{17}\end{array}$ \\
\hline 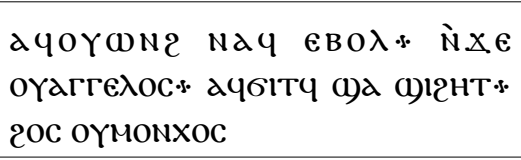 & رظظبر له ملاك صحبه الى شيهات في شبه & $\begin{array}{l}\text { An angel appeared to him and } \\
\text { took him }{ }^{18} \text { to Scetis as a monk }\end{array}$ \\
\hline 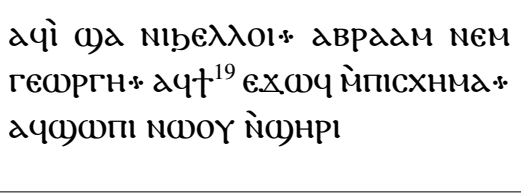 & 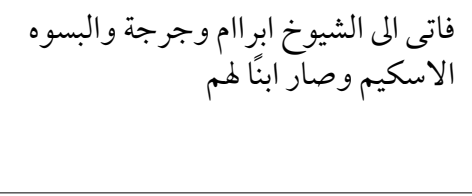 & $\begin{array}{l}\text { He came to the elders Abraham } \\
\text { and George and they clothed } \\
\text { him with the schema, and he } \\
\text { became a son to them }\end{array}$ \\
\hline 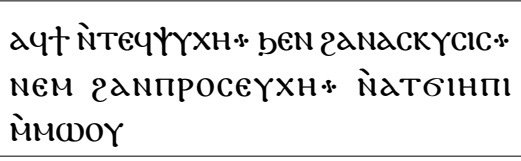 & تحصى نقع نفه في نسكيات وصلو ات لا & $\begin{array}{l}\text { He gave his soul in ascetic } \\
\text { (practices) and countless prayers }\end{array}$ \\
\hline 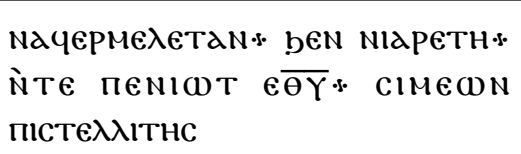 & وكمان يقرى في فضايل ابينا القديس & $\begin{array}{l}\text { He used to meditate } e^{20} \text { in the } \\
\text { virtues of our holy father } \\
\text { Simeon the Stylite }\end{array}$ \\
\hline 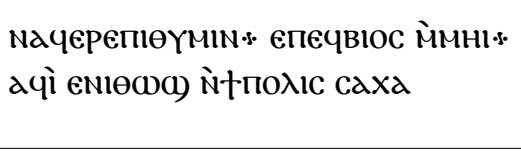 & ويشتاق الى سيرته الحقيقة فنزل الى مدينة & $\begin{array}{l}\text { He desired eagerly his true life } \\
\text { he went to the borders of the } \\
\text { city of Sakha }\end{array}$ \\
\hline 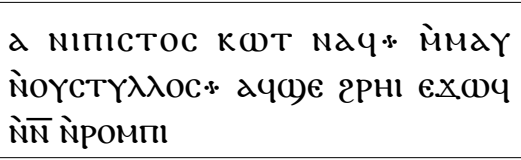 & مرة خمسون سنة بنو المونو لهموداً فصعد عليه & $\begin{array}{l}\text { The faithful built to him there } \\
\text { a pillar he went up for fifty } \\
\text { years }\end{array}$ \\
\hline 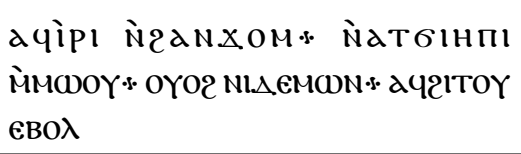 & وثثرة قوات لا يحصون واخرج شياطين & $\begin{array}{l}\text { He did countless miracles and } \\
\text { he casted the demons }{ }^{21} \text { out }\end{array}$ \\
\hline
\end{tabular}

16 Arabic "without ceasing."

17 Lit. "his heart"

18 Arabic "accompanied"

19 Read art

20 Arabic "read"

21 Arabic “+many." 


\begin{tabular}{|c|c|c|}
\hline 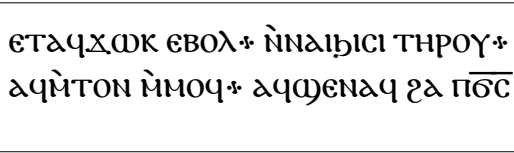 & 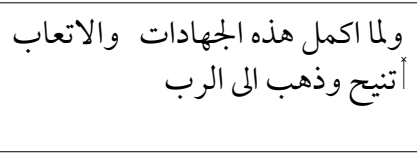 & $\begin{array}{l}\text { He completed all these pains }{ }^{22} \\
\text { and reposed and went to the } \\
\text { Lord }\end{array}$ \\
\hline 2ITEN NIEYXH & .... بصلوات & Through the prayers \\
\hline
\end{tabular}

\section{Commentary}

The quatrain is an introductory text praising the virtues of the saint. The second quatrain highlights the origin of the Saint from Tinnis (1992, p. 2686-2694). The following quatrain are parallel to the text of the Synaxarium. The names of Abraham and George are "the last great saints", of Scetis in the seventh century (Coquin, 1991, pp. 12a-13a; Evelyn-White, 1932, pp. 278-80). It is important to mention that this saint lived in Lower-Egypt around the sixth-seventh century which means that it was around the time of important events such as the usurper of Phocas, the Persian invasion, the Byzantine reconquest, and the Arabic conquest (Fraser, 1991, p. 183b-189b). However no mention of any of these events in biography of this saint. The city of Sakha it is worth mentioning that the spelling of the name of the city is not attested elsewhere (Timm, 1992, p. 2231-2237), it seems that it was taken from the Arabic text.

The text briefly mentions the miracles without giving details. Hence, we can say that the text of the Difnar here is relaying on the Synaxarion for the following reasons:

- The spelling of the city Sakha is taken from Arabic.

- The same could be said for the spelling of city Tannīs.

- The biographical data are taken from the synaxarion without adding anything.

\begin{tabular}{|c|c|c|}
\hline Ǹ̈OY ON HXOC BATOC & وله ايضا طرح واطس & To him also tune Batos \\
\hline 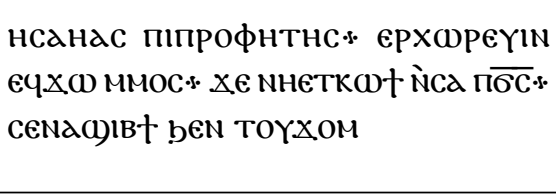 & 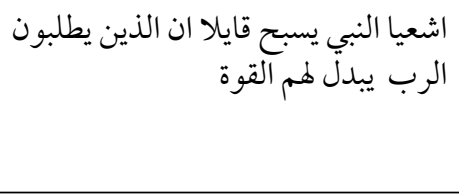 & $\begin{array}{l}\text { Isaiah the prophet sings } \\
\text { saying: "Those who wait for } \\
\text { the Lord shall change their } \\
\text { strength." }{ }^{23}\end{array}$ \\
\hline 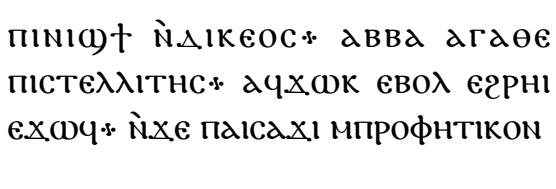 & قد كما الصديق عليه هذا القظيم انبا اغاثا العمودي النبوي & $\begin{array}{l}\text { The great righteous } \\
\text { Abba Agathon the stylite } \\
\text { accomplished upon him this } \\
\text { prophetic statement }\end{array}$ \\
\hline
\end{tabular}

22 Arabic + "fighting, struggling"

23 Is. 40: 31. 


\begin{tabular}{|c|c|c|}
\hline 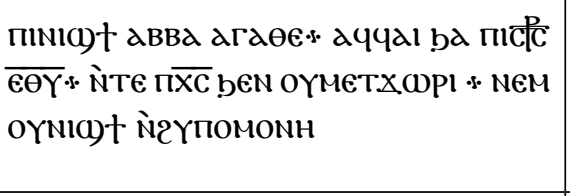 & الذي المسيح انبا بقوة وصل الصبر عظيم المقدس & $\begin{array}{l}\text { The great abba Agathon } \\
\text { carried the holy Cross of } \\
\text { Christ with mighty and great } \\
\text { endurance }\end{array}$ \\
\hline 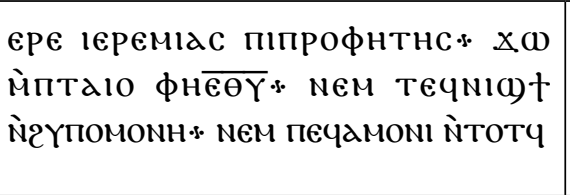 & 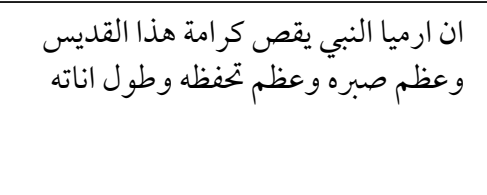 & $\begin{array}{l}\text { Jeremiah the prophet said } \\
\text { about the honour of the } \\
\text { saint and his great endurance } \\
\text { and his possession }\end{array}$ \\
\hline 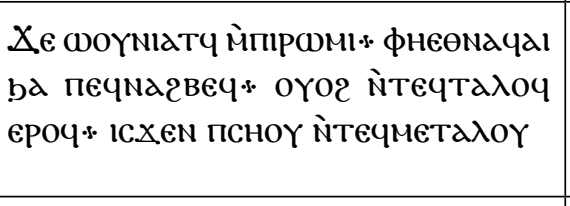 & على عاتقه منذ زمان الذ الذي يحمل عليه نيره & $\begin{array}{l}\text { Saying: "Blessed is the man } \\
\text { when he bears his yoke and } \\
\text { carries it to him since the } \\
\text { time of his youth." } 24\end{array}$ \\
\hline 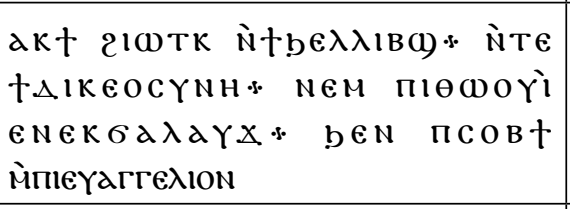 & قدميك بعده الانجيل قدع البر وانعلت & $\begin{array}{l}\text { You wore on the breastplate } \\
\text { of righteousness; and } \\
\text { your feet shod with the } \\
\text { preparation of the Gospel. }\end{array}$ \\
\hline 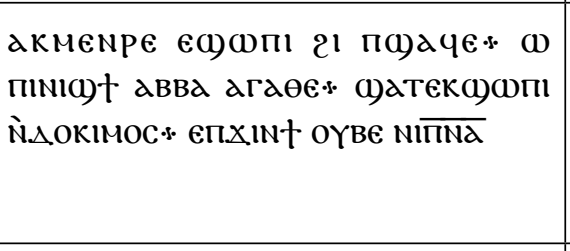 & 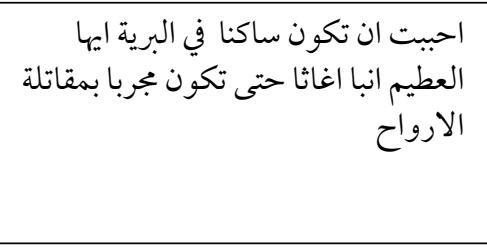 & $\begin{array}{l}\text { You loved to dwell in } \\
\text { the desert, O great Abba } \\
\text { Agathon in order to be } \\
\text { tempted in the fight of the } \\
\text { Spirit. }\end{array}$ \\
\hline 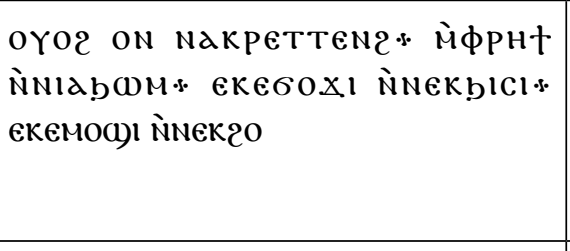 & و وانبتت لكب اجنتحة مثل النسور اذا تسعى ولا تعطش & $\begin{array}{l}\text { And also wings grew like } \\
\text { eagles, you hastened, and } \\
\text { you did not tire and you } \\
\text { walked and you did not } \\
\text { become hungry }{ }^{26}\end{array}$ \\
\hline 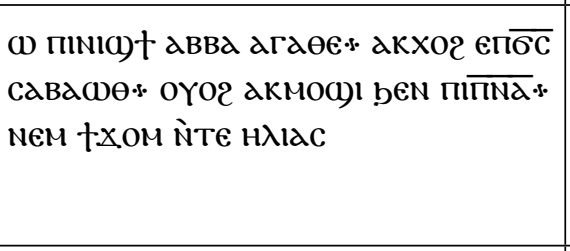 & الصاباووت العظم انبا اغاثا فاغترت للربت بالروح وبقوة ايليا & $\begin{array}{l}\text { O great Abba Agathon, you } \\
\text { became zealot for the Lord } \\
\text { of Hosts and you walked in } \\
\text { the Spirit and the power of } \\
\text { Elijah }\end{array}$ \\
\hline 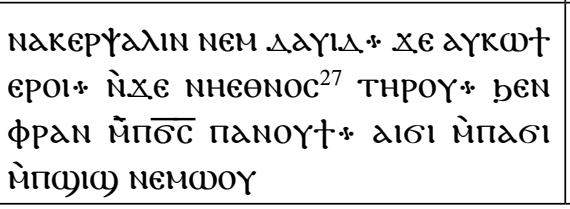 & 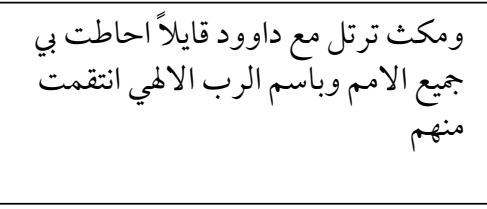 & $\begin{array}{l}\text { You used to sing with David: } \\
\text { "All nations surrounded me, } \\
\text { in the name of the Lord, my } \\
\text { Lord I fended them off!" } 28\end{array}$ \\
\hline
\end{tabular}

24 Lamentations 3:7.

25 phessians 6:14-15.

26 Arabic "thirsty."

27 Read nieenoc

28 Ps 117 [118]: 10 


\begin{tabular}{|c|c|c|}
\hline 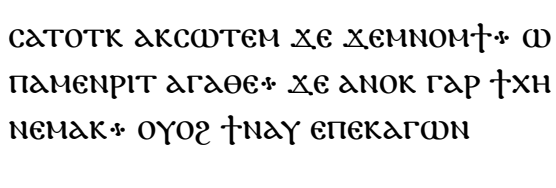 & ولاني كاين معك ومعت تقوي يا حانظ المبيبي اغاثا & $\begin{array}{l}\text { Immediately you heard: } \\
\text { "console O my beloved } \\
\text { Agathon for I am with you } \\
\text { and I see your fight." }\end{array}$ \\
\hline 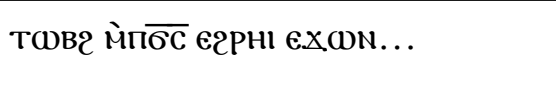 & اطلب من الرب & $\begin{array}{l}\text { Pray to the Lord on our } \\
\text { behalf... }\end{array}$ \\
\hline
\end{tabular}

\section{Commentary}

The psali Batos does not provide biographical data about Agathon of Scetis. The author of this text has excellent knowledge of Scriptures mentioning verses from the Old and the New Testaments. The text could apply to any hermit or monk, we do not find any anthroponym or toponym. While the Psali Adam provides us with much information about his origin, his two masters Abraham and George in Scetis, his withdrawal to Sakha, etc.

\section{Conclusion}

In this article, we highlighted the importance of the city of Sakha (Stewart, 1991, p. 2087b-2088a), in the book of history of the Patriarchs, the book of the Churches and Monasteries (twelfth century). This saint lived in Lower-Egypt around the sixth-seventh century which means that he was contemporary to important events such as the usurper of Phocas, the Persian invasion, the Byzantine reconquest, and the Arabic conquest, but neither his biography nor the liturgical texts reflect any hints of these events. We found two sets of the liturgical texts are additional sources of information to our knowledge about Agathon the Stylite. A doxology Batos rarely attested in many manuscripts. Texts of the Antiphonarion (Difnar). These texts do not add much about the biographical data; however they show the interest and the veneration of this saint. Interestingly, while the pillar of Simeon the Stylite was remembered and venerated for long (Maraval, 1985, pp. 342-345) time, the pillar of Agathon is not mentioned anywhere, even his relics are not found. The church is considered as one of the places visited by the holy family. ${ }^{29}$

\section{References}

'Abd al-Masih, Y. (1941). Doxlogies in the Coptic Church -unedited Bohairic doxologies I Tût -Kyahk. Bulletin de la Société d'Archéologie Copte 731-61.

29 Hulsman, 2002, p.50-52. A. et B. Sadek, 2017, p.136-140. However these traces should be that of Severus of Antioch cf. Youssef, 2001, p. 71-76. 
'Abd al-Masih, Y. \& Burmester, O.H.E. (1943) History of the Patriarchs of the Egyptian Church known as the History of the holy Church, volume 2 part 1, Khaël II -Shenouti I, Textes et documents. Le Caire: Société d'Archéologie Copte.

Atiya, A. S., 'Abd al-Masih Y. \& Burmester, O.H.E. (1948). History of the Patriarchs of the Egyptian Church known as the History of the holy Church, volume 2 part 2, Khaël III -Šenouti II, Textes et documents. Le Caire: Société d'Archéologie Copte.

Atiya, A. S. 'Abd al-Masih Y. and Burmester, O.H.E. (1959). History of the Patriarchs of the Egyptian Church known as the History of the holy Church, volume 2 part 3, Christodoulus -Michael, Textes et documents. Le Caire: Société d'Archéologie Copte.

Atiya, A. S. (1991). “Abu Jirja”. Coptic Encyclopedia. A.S. Atiya (ed.) volume 1. New York: MacMillan.

Atiya, A.S. (1991). “Harit al-Rum”. Coptic Encyclopedia. A.S. Atiya (ed.) volume 4. New York: MacMillan.

Al-Suriani, S. (1984). Tarikh al-kana'is wal-adyara. Cairo: Coptic Institute.

Al-Suriani, S. (1990). Icônes et iconographie d'après le manuscrit d'Abu el-Makarim, publié en arabe au Caire 1984. Le Monde Copte (18), 78.

Basset, R. (1904). Le Synaxaire Arabe Jacobite, (rédaction Copte), 2 Mois de tout et de Babeh. Patrologia Orientalis 1.3 (3). Paris: Firmin-Didot.

Burmester, O.H.E. (1938). The Turuhat of the Saints (Tût, Bâbah, Hatûr). Bulletin de la Société d'Archéologie Copte (4), 141-194.

Butler, A. J. (1887). The Ancient Coptic Churches of Egypt. Oxford: Clarendon Press.

Chaîne, M. (1948). La vie et les miracles de saint Syméon stylite l'ancien, Bibliothèque d'Études Coptes 3. Le Caire: Institut Français d'Archéologie Orientale.

Coquin, R.G. (1975). Le Calendrier Copte des fêtes de saints chez al-Qalqašandî. Parole de l'Orient, 6(7), 375-411.

Coquin, R.G. (1991). "Abraham and George of Scetis, saints," Coptic Encyclopedia. A.S. Atiya (ed.) volume 1. New York: MacMillan.

Cramer M. and Krause, M. (2008). Das koptische Antiphonar, Jerusalemer Theologisches Forum 12. Münster: Aschendorff Verlag.

De Fenoyl, M. (1960). Les sanctoral Copte, Recherches publiés sous la direction de l'Institut de Lettres Orientales de Beyrouth 15. Beyrouth: l'Institut de Lettres Orientales.

Den Heijer, J. (1993). The Composition of the History of the Churches and Monasteries of Egypt -Some preliminary remarks. In Acts of the Fifth International Congress of Coptic Studies Washington 12-15 August 1992. D. Johnson, (ed .). Roma: CMCL.

Den Heijer, J. (2007). Le vizir fatimide Badr al-Ğamālī (466/1074-487/1094) et la nouvelle muraille du Caire: Quelques remarques préliminaires. Egypt and Syria (5), 91-107.

Detlef, G. \& Müller, C. (1991). "Agathon of Alexandria”. Coptic Encyclopedia. A.S. Atiya (ed.) volume 1. New York: MacMillan.

Detlef, G. \& Müller, C. (1991). "Zacharias, Saint". Coptic Encyclopedia, A.S. Atiya (ed.) volume 7. New York: MacMillan. 
Evelyn-White. H. G. (1932). The Monasteries of the Wadi 'n Natrun, Part 2. New York: Metropolitan Museum of Arts.

Evetts B.T. \& Butler, A.J. (1895). The Churches and Monasteries of Egypt and some Neighbouring countries, attributed to Abû Salih the Armenian. Oxford.

Evetts, B. T. (1909). History of the Patriarchs of the Coptic Church of Alexandria, III Agathon to Michael I (766). Patrologia Orientalis 1, 4(4).

Forget, I. (1905). ”Synaxarium Alexandrinum". Corpus Scriptorum Christianorum Orientalium 1 Arabic 18. Paris: Poussielgue.

Fraser, P. M. (1991). “Arab conquest of Egypt”. Coptic Encyclopedia, A.S. Atiya (ed.) volume 1. New York: MacMillan.

Gabra, G. (1996). Untersuchungen zum Difnar der Koptischen Kirche. Bulletin de la Société d'Archéologie Copte (35), 37-52.

Gabra, G. (1998). Untersuchungen zum Difnar der Koptischen Kirche. Bulletin de la Société d'Archéologie Copte (37), 48-69.

Hulsman, C. (2002). Tracing the route of the Holy Family Today. Be thou there, the Holy Family's journey in Egypt, G. Gabra (ed.) (pp.50-52). Cairo-New York: The American University in Cairo Press.

Hyvernat, H. (1886-1887). Les Actes des martyrs de l'Égypte tirés des manuscrits coptes de la Bibliothèque Vaticane et du Musée Borgia. Paris.

Khater A. and Burmester, O.H.E. (1970). History of the Patriarchs of the Egyptian Church, Textes et documents 13. Le Caire: Société d'Archéologie Copte.

Krause M. ( 2003). Das koptische Antiphonar aus dem Handschriften von Hamuli. In Agypten-Münster, Kulturwissenschaftliche Sutdien zu Agypten, dem Vorderen Orient und verwandeten Gebieten (Festschrift E. Graefe). Wiesbaden: Dr. Ludwig Reichert Verlag.

Labib, S. Y. (1991). “Cosmas II”. Coptic Encyclopedia. A.S. Atiya (ed.) volume 2. New York: MacMillan.

Labib, S. Y. (1991). "Cyril II”. Coptic Encyclopedia. A.S. Atiya (ed.) volume 3. New York: MacMillan.

Labib, S. Y. (1991). "Kha’il I”. Coptic Encyclopedia. A.S. Atiya (ed.) volume 4. New York: MacMillan.

Labib, S. Y. (1991). “Kha’il III”, Coptic Encyclopedia. A.S. Atiya (ed.) volume 5. New York: MacMillan.

Maraval, P. (1985). Lieux saints et pèlerinages d'Orient- Histoire et géographie des origines à la conquête arabe. Paris: Cerf.

Martin, M. (1997). Le Delta chrétien à la fin du XIIº s. Orientalia Christiana Periodica (63), 181-199.

Martin, M. (1998). Alexandrie chrétienne à la fin du XII d'après Abû l-Makârim. Alexandrie médiévale 1, edited by C. Décobert and J.Y. Empereur, Études alexandrines 3. Cairo: Centre d'Études Alexandrine.

Martin, M. (2000). Chrétiens et musulmans à la fin du XII siècle. Valeur et distance: Identités et Sociétés en Égypte. Paris.

Martin, M. (2004). Dévotions populaires au Caire à la fin du XII siècle. Aegyptus Christiana, Mélanges d'Hagiographie Égytienne et Orientale dédiés à la mémoire du P. Paul Devos Bollandiste, U. Zanetti et Enzo Lucchesi, (eds.). Cahiers d'Orientalisme XXV, Genève: Patrick Cramer.

Meinardus, O.F.A. (1970). Christian Egypt faith and life. Cairo: American University in Cairo Press.

Meinardus, O.F.A. (1977).Christian Egypt Ancient and Modern. Cairo: American University in Cairo Press. 
Meinardus, O.F.A., (1999). Two thousands year of Coptic Christianity. Cairo: American University in Cairo Press.

Mekhaiel, N. (2010). Untersuchungen zur Entstehungs-und Überliegerungsgeschichte des koptischen Difnars. Jerusalemer Theologisches Forum (14). Münster: Aschendorff Verlag.

Moawad, S. (2014). "Coptic Historiography”. Coptic Civilization two Thousands years of Christianity in Egypt. Gawdat Gabra (editor) A Saint Mark Foundation Book. Cairo New York: American University in Cairo Press.

Mouton J-M. and Popescu-Belis,A. (2006). Une description du monastère Sainte-Catherine du Sinaï au XII é siècle: Le manuscrit d'Abū l-Makārim. Arabica (53), 1-53.

Nau, F. (1913). Les Ménologes des évangéliaires Coptes-Arabes. Patrologia Orientalis 10. 2(47). Paris: Firmin-Didot.

Papaconstatinou, A. (2001). Le Culte des Saint en Égypte des Byzantins aux Abbassides, l'apport des inscriptions et des papyrus grecs et coptes. Le Monde Byzantin. Paris: CNRS.

Porcher, E. (1915). Mina, évêque de Pchati, Vie d'Isaac, patriarche d'Alexandrie de 686- 689. Patrologia Orientalis 11(3). Paris: Firmin-Didot.

Sadek, A. et B. (2017). Un fleuve d'eau vive trilogie sur l'entrée du Christ en Égypte, Tome 2, Les sites guide du voyageur. Le Monde Copte : Limoges.

Stewart, R. (1991). "Sakha”. Coptic Encyclopedia, A.S. Atiya (ed.) volume 7.New York: MacMillan.

Seybold, C. F. (1904). Severus ben El Moqaffa', Historia Patriarcharum Alexandrinum, 1(1), Corpus Scriptorum Christianorum Orientalium 52. Paris: Carolus Poussielgue.

Seybold, C. F. (1912). Severus Ibn al-Muqaffa' Alexandrinische Patriarchen-geschichte von S. Marcus bis Michael 61767. Hamburg: Lucas Gräfe.

Sidarus, A. Y. (1975). Ibn ar-Râhibs Leben un Werk. Islmakundliche Untersuchengen Band 36. Freiburg: Klaus Schawrz Verlag.

Timm, S. (1986-1992). Das christlich-koptische Ägypten in arabischer Zeit. Tübinger Atlas des Vorderen Orients 41. Wiesbaden: Dr. Ludwig Reichert Verlag.

Tisserant, E. (1913). Le calendrier d'Aboul-Barakat. Patrologia Orientalis 10.3(48). Paris: Firmin-Didot.

Viaud, G. (1979). Les pèlerinages Coptes en Égypte d'après les notes du Qommos Jacob Muyser. Bibliothèque d'Études Coptes 15. Le Caire: Institut Français d'Archéologie Orientale.

Viaud, G. (1991). "Pilgrimages” Coptic Encyclopedia. A.S. Atiya (ed.) volume 6. New York: MacMillan.

Youssef, Y.N. (1998-1999). Multiconfessional churches in Egypt during the XII Century. Bulletin of Saint Shenouda the Archmandrite Coptic Society (5), 45-54.

Youssef, Y.N. (2001). Ancient and Modern legends concerning the Holy Family in Egypt. Coptic Church Review 22(3), 71-76.

Youssef, Y. N. (2004). The Arabic life of Severus of Antioch attributed to Athanasius. Patrologia Orientalis 49, 4(220). Pontificio Istituto Orientale -Roma. Turnhout: Brepols.

Youssef, Y. N. (2006). A Homily on Severus of Antioch by a bishop of Assiut. Patrologia Orientalis 50, 1(222). Pontificio Istituto Orientale -Roma. Turnhout: Brepols.

Zanetti, U. (1995). Abu L-Makarim et Abu Salih. Bulletin de la Société d'Archéologie Copte (34), 85-133. 
Zanetti, U. (1996). Vie de S. Jean, Higoumène de Scété au VII siècle. Analecta Bollandiana (114), 273-405.

Zanetti, U. (2015). S. Jean, Higoumène de Scété (VIIe siècle). Vie Arabe et épitomé éthiopien. Subsidia Hagiographica (94). Bruxelles: Société des Bollandistes.

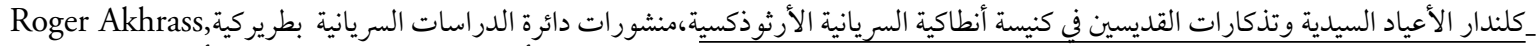
أنطاكية وسائر المشرق للشريان الأرثوذكس of Antioch the Syriac Orthodox, Publications of the centre of the Syriac studies,] Damascus: Patriarchate of Antioch and all the East for the Syriac Orthodox 2015.

جمدي جرجس، أثر الأرختة على أوضاع القبط في القرن الثامن عشر،

[Magdi Girgis, The influence of the notables on the situations]

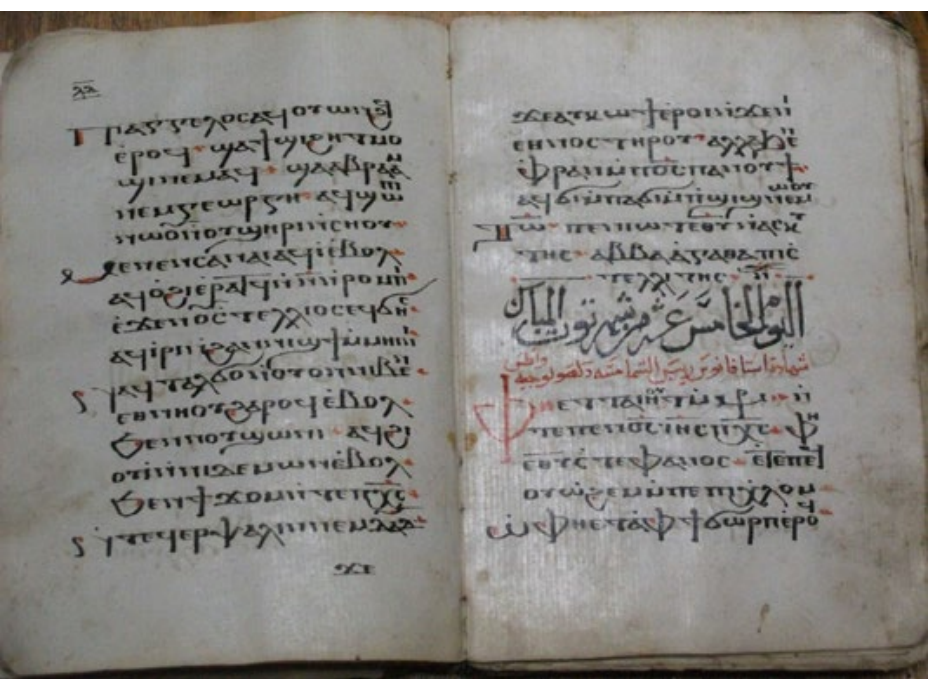

Ms 75 Liturgy Sammanud fol. 34.

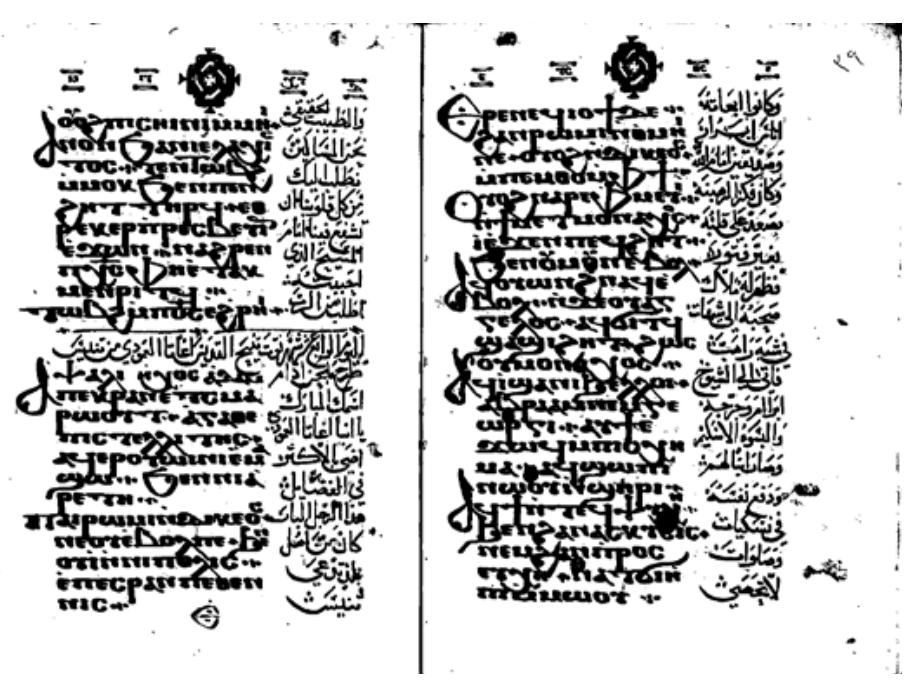

Coptic Museum, Ms 357 Liturgy fol. 40v 